\title{
An Index of Socio-Economic Well-Being of U.S. Farm Households
}

\author{
Hisham S. El-Osta \\ Economic Research Service, Washington DC, USA ${ }^{*}$ \\ Email: helosta@ers.usda.gov \\ Received 1 October 2014; revised 1 November 2014; accepted 14 November 2014 \\ Copyright (C) 2014 by author and Scientific Research Publishing Inc. \\ This work is licensed under the Creative Commons Attribution International License (CC BY). \\ http://creativecommons.org/licenses/by/4.0/ \\ (c) (7) \\ Open Access
}

\begin{abstract}
The primary purpose of the paper is to construct a combined index of quality-of-life and economic wellbeing based on national data from the 2004 Agricultural Resource Management Survey. Additional objective is to assess the role of increased utilization of various types of Federal farm programs in the context of the life-cycle on socioeconomic wellbeing. A central finding, which has implication for rural development and the continuity of the family farm, shows a positive relationship between increased intensity of farm program participation and higher likelihoods of socioeconomic wellbeing, particularly among elderly farmers.
\end{abstract}

\section{Keywords}

Farm Programs, Multinomial Probit Regression, Quality of Life, Socio Economic Wellbeing

\section{Introduction}

Many economists in the United States have for many years documented the benefit of using the income and wealth levels of farm households as indicators of their economic well-being [1]-[3]. The driving force of these studies was the nation's farm policy since the 1930s with its concern of providing parity between farm and nonfarm households [4]-[6]. Mishra et al. (2002) [3], based on a joint income and wealth analyses, showed only 6 percent of U.S. farm households suffered both lower incomes and lower wealth than the median income and median wealth of all U.S. households in 2000. In contrast, almost 50 percent of U.S. farm households in 2000 had both higher incomes and greater wealth than all U.S. households. In 2012, nearly 63 percent of U.S. farm households had income and wealth above the median levels of U.S. households, pointing to a measurable improvement in farm household economic well-being. While parity indicators are no longer relevant in the formulation of farm policy, public interest in the general well-being of both farm and non-farm households, and how

\footnotetext{
${ }^{*}$ The views expressed in the paper are the author's and do not necessarily represent the policies or views of U.S. Department of Agriculture.
} 
such well-being is measured and ascertained, persists. ${ }^{1}$

The primary objective of the study is to seek a measure of farm households' well-being that combines into an index both the economic and the social components of well-being. The second objective is to assess the association between various characteristics (i.e., operator, farm household and farm business, and macro-economic and labor market conditions) and this socio-economic index using discrete multivariate regression procedures in order to discern which of the variables considered might be relevant, from a farm production decision and policy perspective, to improve the living standards and the quality of life of farm households. Two variables in particular are perceived to be most relevant: the role of farmers' age and the extent of participation by the farm household in Federal farm programs.

In terms of farmers' age, this stems from the generally accepted notion of the impact of the life-cycle on households' income and wealth levels [9] and on farm survival [10] [11] in addition to farm growth and patterns of exit and entry into farming [12] [13]. The relevance of age when examining the well-being of those households involved in farming becomes more apparent particularly when viewed in the context of data from the Agricultural Census that seems to suggest an aging farm operator, with operators' average age rising from 50.3 in 1978 to 57.1 in 2007. The fastest growing group of farm operators is that of those aged 65 years or older [14], which based on more recent data from the 2012 Agriculture and Resource Management Survey (ARMS), account now for 31 percent of all farm operators.

With regard to the potential impact of participation in farm programs, data from the 2012 ARMS showed that 33 percent of the 2.1 million farm households participated in Federal farm programs, with an average payment for the reporting farm household of $\$ 11,515$ or nearly $\$ 8$ billion across the whole population of farm households. Previous research, however, has shown that the high level of farm payments expended by the federal government in the late 1990s (e.g., increasing from \$7.3 billion in 1996 to \$21.5 in 1999, or adding up to a total for the period of $\$ 48.7$ billion) did little to eradicate the long-term outmigration from farming areas [15], with adverse impact on local communities. Yet to the extent that many farm households participate in government programs to mitigate the effects of agricultural risk on farm family household income [16]-[18], farm subsidies may contribute to the economic well-being of farm households both in terms of fostering income levels and through appreciation of land values due to the capitalization of payments [19], and due to the favorable impact on local communities of higher farm household spending.

As noted by El-Osta and Morehart [9], household resource allocation decisions are, in part, determined by a person's age and family circumstances-the factors that shape their life cycle. Yet other studies have linked farm program payments to household resource allocation decisions as well [20]-[22]. In light of the potential impact of age and farm subsidies on farm production decisions, the contribution of this paper is to try to assess the linkages of these factors, as measured respectively in terms of the farmer's stage in the life cycle and the intensity of participation in farm programs, to the socio-economic well-being of farm households.

\section{Data and Methods}

The primary data source is the 2004 ARMS. The ARMS, which has a complex stratified, multi-frame design, is a national survey conducted annually by the National Agricultural Statistics Service and the Economic Research Service of the U.S. Department of Agriculture. ${ }^{2}$ Each observation in the ARMS represents a number of similar farms (e.g., based on land use, size of farm, etc.), the particular number being the survey weight which is the inverse of the probability of the surveyed farm being selected for surveying. The size of the sample considered in the analysis is 6706, which when properly expanded using ARMS survey weights yielded a population of farm operator households totaling 2,067,373.

The latent response variable $\left(I^{*}\right)$ used in the study has social and economic dimensions. The social dimension is based on a list of 10 quality-of-life items (QOL) in the 2004 ARMS questionnaire, as shown in the top panel

\footnotetext{
${ }^{1}$ A case in point is the remark by the Federal Reserve Chairman Ben Bernanke at an Income and Wealth Conference (32 ${ }^{\text {nd }}$ General Conference of the International Association for Research in Income and Wealth, in Cambridge, Massachusetts, Aug. 6, 2012 [7]) that suggested to economists to seek a better measurement of well-being. Specifically, the suggestion was to advocate going beyond just the use of aggregate measures such as gross domestic product and personal consumption expenditures to assess national well-being and to look at alternative measures of well-being that are frequently survey-based, and that tend to incorporate elements such as, among others, the level of education, physical health and safety, community vitality and the strength of family and social ties, and time spent in leisure activities. Also, see the study by Strickland (1982) [8] that provides indicators of farm earnings other than just net-farm income.

${ }^{2}$ For more detail about the ARMS, see http://www.ers.usda.gov/Briefing/ARMS/. The reason for using data from the 2004 ARMS and not from a more recent survey year is that 2004 was the only year when data that are needed for this research on the quality-of-life attributes of the communities where farmers tend to live were collected.
} 
of Figure 1, which included questions that asked the respondent to rate each of the items based on a 3-level rating scale: whether the item is perceived to be "a major problem”, "a minor problem”, or "not a problem/does not apply". Responses to each of the 10 items were re-coded as 1 if the reported perception of the particular item by the operator was that of "a major problem" (referred to as "deficit" henceforth); 0 otherwise. A response-weighted QOL disadvantage index was then constructed based on the weighted summation of these recoded 10 dummyvariable-like items. The weights considered, in percentage term, and as shown in the lower panel of Figure 1, were based on the proportion of households reporting the presence of a major deficit in a particular item relative to the total proportions of all households reporting deficits in all 10 items. The resulting QOL disadvantage index had a range of $0 \%-100 \%$. As seen in the left side panel of Figure 2, a farm household was placed in the qualityof-life "advantaged" category (coded as 1; 0 otherwise) if the deficit score for the QOL disadvantage index was

Frequency

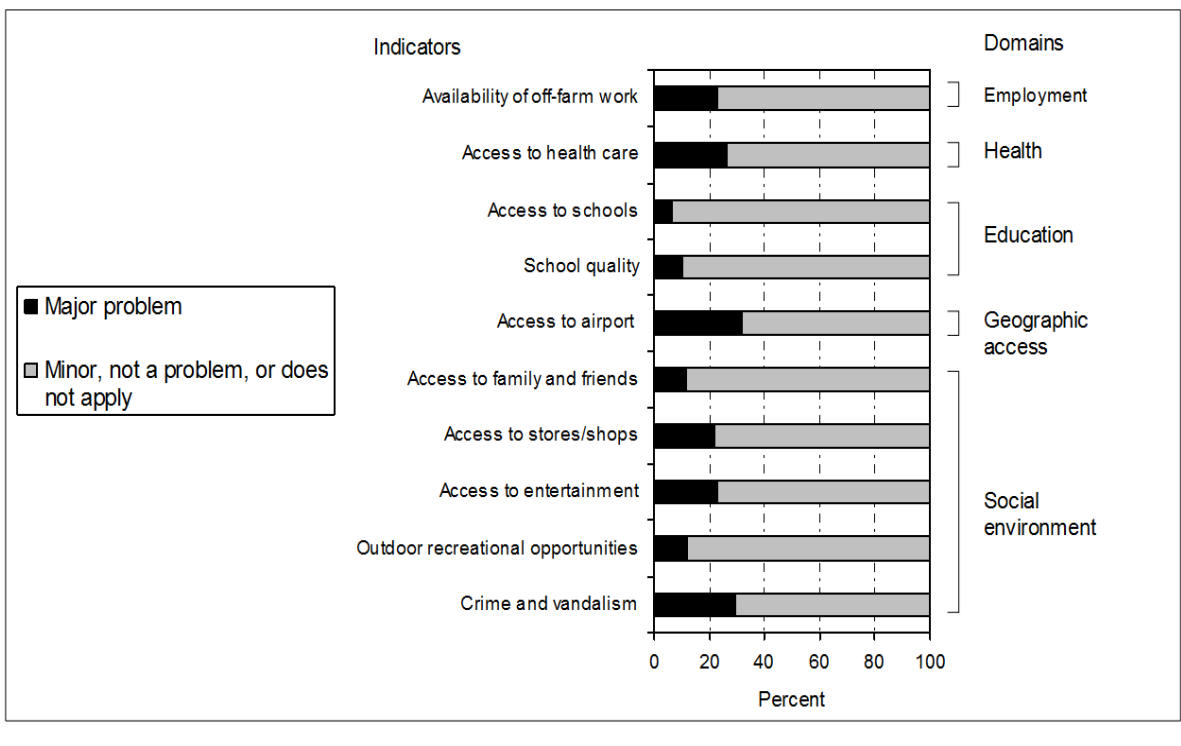

Weights

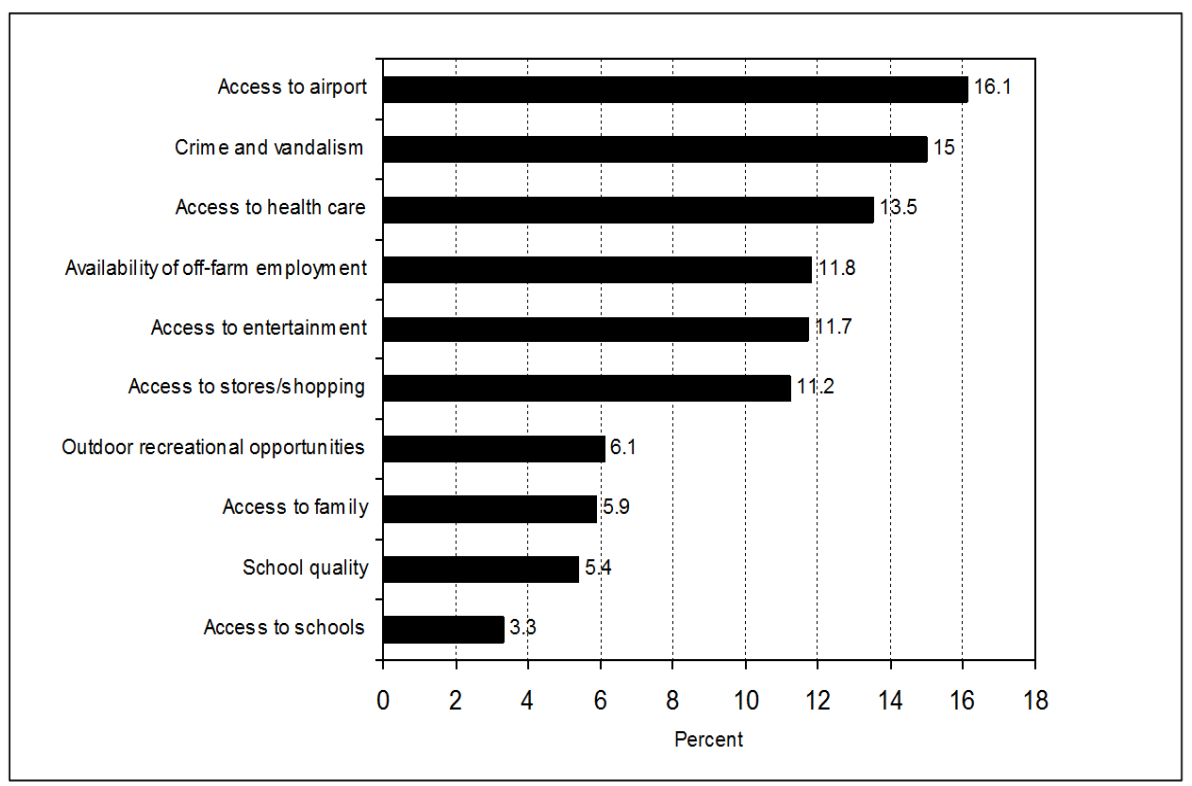

Source:2004 Agricultural Resource Management Survey.

Figure 1. Relative frequency and weights of reported deficits in indicators of quality of life for farm operator households, 2004. 

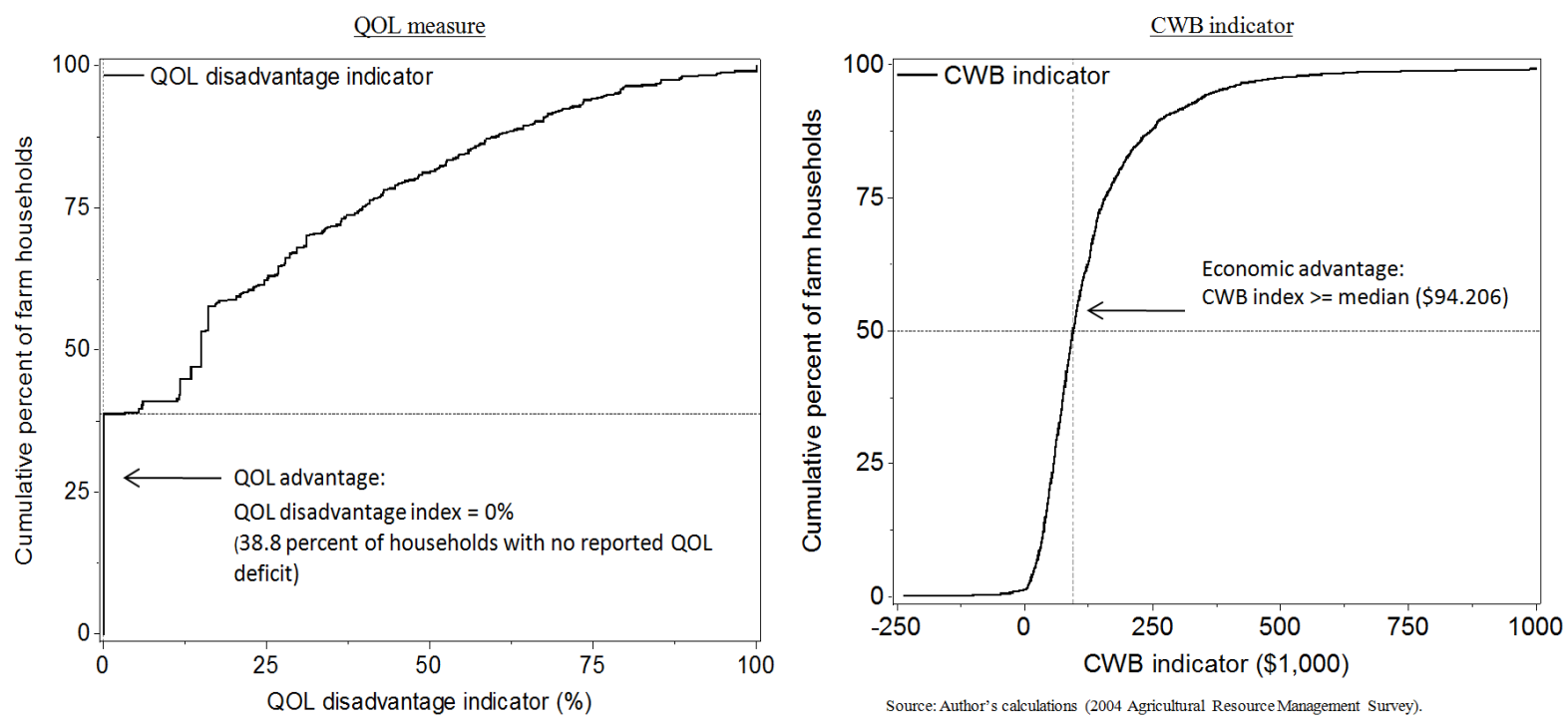

Figure 2. Weighted cumulative distributions of quality of life (QOL) disadvantage measure and economic well-being (CWB) among farm operator households, 2004.

equal to zero, which when tallied on the cumulative distribution, accounted for nearly 38.8 percent of all of the farm households.

The economic dimension is based on a composite measure of well-being (CWB) where all farm household money income (HHMI) and the annualized value of the household's wealth [i.e., farm and non-farm net worth $(N W)$ ] are combined (for more detail, see [23]). A farm household is considered economically advantaged (coded as 1; 0 otherwise) if its pretax value of $C W B$ was greater or equal to the median $C W B$ threshold of all farm operator households, which in 2004 was at $\$ 94,206$. The placement of farm households based on these two economically distinct groups is captured in the right hand side panel of Figure 2 which depicts the cumulative distribution of $C W B$.

The 0 - 1 coded economic and quality of life indices allowed for the construction of the unified economic and quality of life advantage index $(I)$. This resulting index captures four possible socio-economic discrete well-being outcomes facing farm operator households $(M)$ : "economic advantage only" (30.3\%), "social advantage only" (19.1\%), "both types of advantages" (19.7\%), and "socio-economic disadvantage" (30.9\%), which comprises the base category. Figure 3 shows the scatter plot of the weighted sample (with the size of the bubble capturing the magnitude of the survey weight) and the distribution of farm households based on these four discrete socioeconomic outcomes. ${ }^{3}$ Factors perceived to impact socio-economic well-being as captured by the dependent variable $\left(I^{*}\right)$ were estimated using a multinomial probit (MNP) model (see [24] [25]). The MNP model and the resulting probability $(P)$ that the $i^{\text {th }}$ farm household falls in the $j^{\text {th }}$ "advantaged" category and not in the $q^{\text {th }}$ category that denotes socio-economic advantage are captured, respectively, by the vector $I_{i} \in\{1,2,3,4\}$ and $P_{i j}$ :

$$
\begin{aligned}
I_{i}^{*}=\beta_{0} & +\sum_{k=1}^{4} \beta_{k} A_{k i}+\beta_{5} N_{5 i}+\sum_{k=6}^{K} \beta_{k} Z_{k i}+\varepsilon_{i}=\beta^{\prime} X_{i}+\varepsilon_{i}, \quad \varepsilon_{i} \approx M V N(0, \Sigma), \text { for } i=1, \cdots, n, \\
P_{i j} & =\operatorname{Pr}(j \mid \beta, X, \Sigma)=\operatorname{Pr}\left\{\varepsilon_{i j}-\varepsilon_{i q} \leq\left(X_{i q}-X_{i j}\right)^{\prime} \beta\right\}, \quad j \neq q, \text { for } j=1, \cdots, M-1 \\
& =\int_{-\infty}^{\beta_{1}^{\prime} X_{1}} \cdots \int_{-\infty}^{\beta_{M-1}^{\prime} X_{M-1}} f\left(\varepsilon_{i 1}, \cdots, \varepsilon_{i M-1}\right) \partial \varepsilon_{i 1} \cdots \partial \varepsilon_{i M-1},
\end{aligned}
$$

where $I_{i}^{*}$ is a latent response index, $A_{1 i}$ is the first of four dummy variables representing four distinct groups of farmers' age, $N_{5 i}$ is a count variable that captures the number of the various types of farm programs that the $i^{\text {th }}$

\footnotetext{
${ }^{3}$ While the percentage distribution shown in the Figure reflects the distribution of all farm households in the 48 contiguous states in 2004, the Figure itself excludes those households whose levels of $C W B$ exceed the range depicted in the $x$-axis of the Figure. This was done to allow for a clearer visualization of where the bulk of the households are located with regard to the reference median-CWB of all farm households as depicted in the Figure.
} 


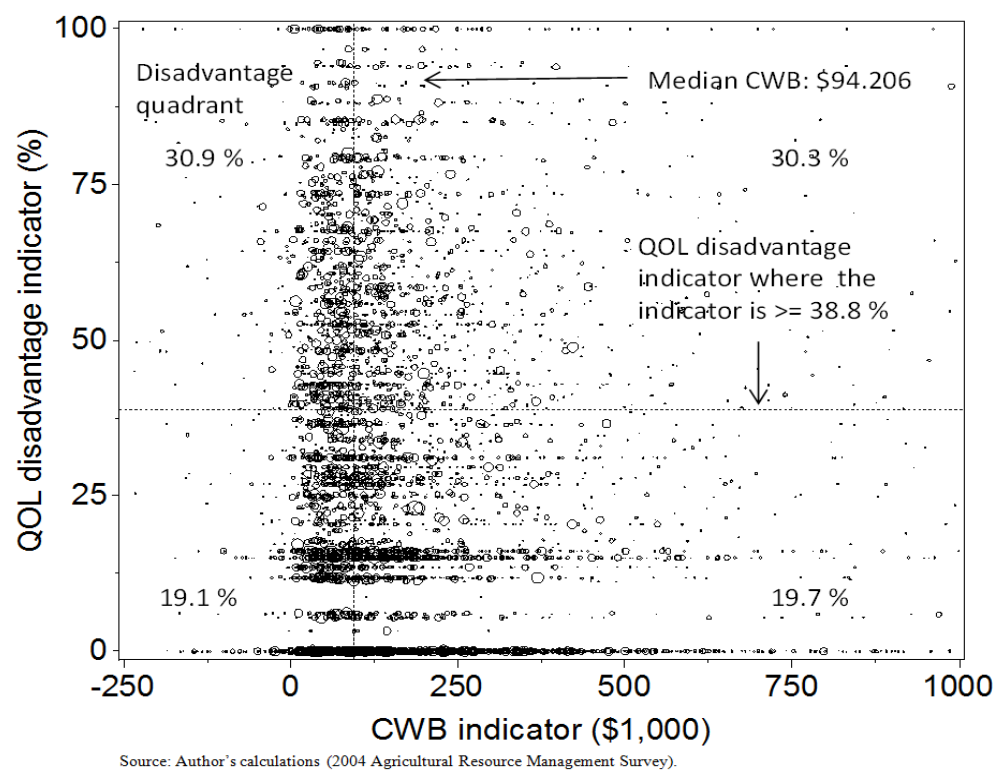

Figure 3. Weighted distribution of farm operator households by status of socio- economic advantage, 2004.

operator participates in, and $Z_{k i}$ represents a set of continuous and dummy variables tailored at capturing other farm operator, farm household and farm business characteristics (e.g., education, gender, marital status, lagged off-farm income, etc.) in addition to variables that describe the labor market characteristics of the county where the farm business is located at, $\beta$ is $K \times 1$ vector of parameters to be estimated, $\varepsilon$ is $(M-1) \times 1$ vector of random disturbances that are multivariate normally distributed, $\Sigma$ is a $(M-1) \times(M-1)$ positive definite covariance matrix, and $f\left(\right.$.) is the probability density function of the multivariate normal distribution. ${ }^{4}$ The $M^{\text {th }}$ designation in (2) represents the base category in the MNP model.

Because some unobserved factors affect both the socioeconomic well-being indicator $I^{*}$ in (1) and the count variable $N$ that captures the number of the various types of farm programs that the operator elects to participate in (e.g., risk preferences, access to markets, commodity prices, etc.), $N$ is potentially an endogenous variable. To remedy this, fitted values from a first stage regression model are used to replace $N$ in (1) as part of the second stage MNP regression.

As evident from Figure 4, the distribution of $N$ is discrete in nature, positively-skewed, and has a prevalence of zeros. Use of a classical linear regression model to predict $N$ is inadequate since such a model is not tailored at dealing with an integer and skewed dependent variable because the distribution of the error terms is no longer homoscedastic or normal [27]. Accordingly, two alternative count-data estimation techniques are considered for a possible use in the derivation of fitted $N$, with each being capable at improving model's fit relative to estimation based solely on least squares regression [28]-[31]:

(A) Poisson regression model:

This model specifies that each element $d_{i}$ of $N$ is drawn from a Poisson distribution with a parameter $\eta_{i}$, which is related to the covariates $x_{i}$ as in:

$$
\begin{aligned}
& \operatorname{Pr}=\operatorname{Probability}\left(N_{i}=d \mid x_{i}\right)=\frac{\mathrm{e}^{-\eta_{i}} \eta_{i}^{d}}{d !}, d \in\{0,1, \cdots, 5\} \text {, with log } \eta_{i}=x_{i}^{\prime} \beta, \\
& \text { and } \eta_{i}=E\left(N_{i} \mid x_{i}\right)=\operatorname{Var}\left(N_{i} \mid x_{i}\right)=\mathrm{e}^{\chi_{i}^{\prime} \beta} .
\end{aligned}
$$

\footnotetext{
${ }^{4}$ The count variable $N(0,1, \ldots, 5)$ takes the value 0 when the farmer does not participate in farm programs, and takes a value between 1 and 5 depending on the number of types of farm programs that the farmer participates in. For example, when the number is 1 , this indicates that the farmer received in 2004 farm program payments from just one source out of the following five available potential sources (for detail on these types of payments, see [26]): direct payments, counter-cyclical payments, loan deficiency payments, Conservation Reserve payments, all other remaining types of payment (e.g., state or local agricultural program payments, market loan payments, Wetland Reserve Program payments, etc.) (number of possible combinations $=5$ ); when the number is 2, this indicates receiving payments from any two of the five available sources (number of possible combinations $=10$ )... and lastly, when the number is 5 , this indicates payments from all five sources (number of possible combinations $=1$ ).
} 


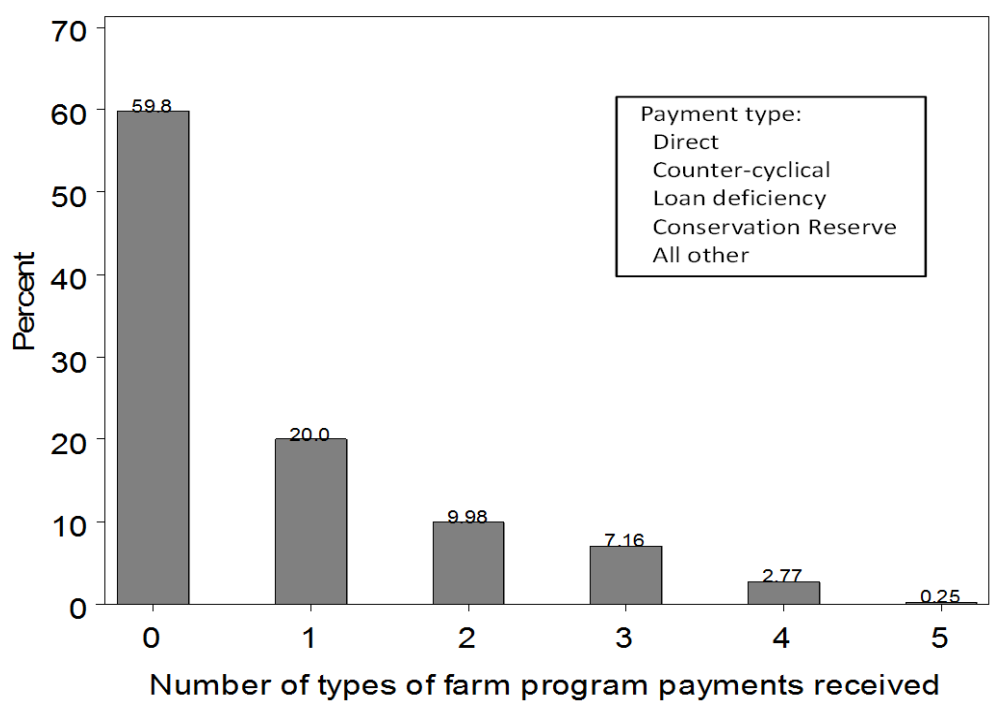

Figure 4. Relative weighted frequency distribution of farm households by counts of farm program payments received, 2004.

In the context of this paper, Equation (3) indicates that the expected number of the various types of farm programs that the $i^{\text {th }}$ operator participates in is equal to the variance of the distribution of $N_{i}$. This property of the Poisson regression, called "equidispersion", seems restrictive, since it is not unlikely to find that the variance of the elements of $N$, particularly due to the preponderance of zeros (e.g., $60 \%$ of the weighted sample) in $N$, is larger than the mean, which implies presence of "over-dispersion" in the underlying data.

(B) Negative binomial (NBN) regression model:

This model relaxes the restriction of the Poisson regression model that conditional mean equals the variance. Accordingly, the Poisson model is generalized by introducing an individual, unobserved effect into the conditional mean $\eta_{i}^{*}$ :

$$
\log \eta_{i}^{*}=x_{i}^{\prime} \gamma+\omega_{i}=\log \eta_{i}+\log \xi_{i},
$$

where $\omega_{i}$ is a specification error or a product of cross-sectional heterogeneity that tends to characterize micro-level data [30]. This leads to the following conditional distribution of $d_{i}$ :

$$
\operatorname{Pr}\left(d_{i} \mid x_{i}, \xi_{i}\right)=\frac{\mathrm{e}^{-\eta_{i} \xi_{i}}\left(\eta_{i} \xi_{i}\right)^{d_{i}}}{d_{i} !},
$$

where $\xi_{i}=\mathrm{e}^{w_{i}}$, and for mathematical convenience, is assumed to have a gamma distribution with parameter $m_{i}$.

The expected value of (5), when taken over $\xi_{i}$, yields the following negative binomial distribution:

$$
\operatorname{Pr}\left(d_{i} \mid x_{i}\right)=\int_{0}^{\infty} \frac{\mathrm{e}^{-\eta_{i} \xi_{i}}\left(\eta_{i} \xi_{i}\right)^{d_{i}}}{d_{i} !} g\left(\xi_{i}\right) \mathrm{d}\left(\xi_{i}\right)=\frac{\Gamma\left(d_{i}+m_{i}\right)}{d_{i} ! \Gamma\left(m_{i}\right)}\left(\frac{m_{i}}{m_{i}+\eta_{i}}\right)^{m_{i}}\left(\frac{\eta_{i}}{m_{i}+\eta_{i}}\right)^{d_{i}},
$$

where $\Gamma$ is the gamma function ([32]; p. 232 for more detail) and where $E\left(\xi_{i}\right)=1$ and $\operatorname{Var}\left(\xi_{i}\right)=1 / m_{i}=\alpha$. The expected value of $d_{i}$ (which is the same as for the Poisson distribution) and its variance (which now differs from that of the Poisson distribution) are:

$$
E\left(d_{i} \mid x_{i}\right)=\mathrm{e}^{x_{i}^{\prime} \gamma}=\eta_{i} \text { and } \operatorname{Var}\left(d_{i} \mid x_{i}\right)=\left(1+\frac{1}{m_{i}}\right) \eta_{i}=(1+\alpha) \eta_{i} \quad \text { for } \alpha>0,
$$

where $\alpha$ is known as the dispersion parameter and is to be estimated.

\section{Results}

Table 1 and Table 2 present, respectively, the summary statistics of variables used in the count model of farm 
Table 1. Summary statistics of variables used in the count model to predict number of farm program payments received, $2004^{1}$

\begin{tabular}{|c|c|c|}
\hline & Weighted & Standard \\
\hline & means & deviations \\
\hline \multicolumn{3}{|l|}{ Operator characteristics } \\
\hline Operator age, years & 57 & 0.28 \\
\hline Operator education, years & 13.29 & 0.05 \\
\hline Occupation of operator: farming/ranching $(=1)$ & 0.4 & -- \\
\hline \multicolumn{3}{|l|}{ Household and farm characteristics } \\
\hline Acreage is fully owned $(=1)$ & 0.6 & -- \\
\hline Farm business has a computer with an Internet access (=1) & 0.54 & -- \\
\hline Farm specializes in the production of cash grains and oilseeds $(=1)$ & 0.12 & -- \\
\hline Farm is located in the Northeast region $(=1)^{2}$ & 0.06 & -- \\
\hline Farm is located in the South region $(=1)^{3}$ & 0.43 & -- \\
\hline Farm is located in the West region $(=1)^{4}$ & 0.13 & -- \\
\hline Sample size & 6706 & \\
\hline Population of farm operator households & $2,067,373$ & \\
\hline
\end{tabular}

${ }^{1}$ Source: 2004 Agricultural Resource Management Survey. Also, the standard deviations of estimates of all continuous variables were estimated using bootstrapping with 1000 resamples. ${ }^{2}$ The Northeast region includes Maine, New Hampshire, Vermont, Massachusetts, Rhode Island, Connecticut, New York, and New Jersey. ${ }^{3}$ The South region includes Kentucky, Tennessee, Alabama, Mississippi, Arkansas, Louisiana, Oklahoma, Texas, Delaware, Maryland, Virginia, West Virginia, North Carolina, South Carolina, Georgia, and Florida. ${ }^{4}$ The West region includes Montana, Idaho, Wyoming, Colorado, New Mexico, Arizona, Utah, Nevada, Washington, Oregon, and California. Note: The base region is the Midwest and it consists of Ohio, Indiana, Illinois, Michigan, Wisconsin, Minnesota, Iowa, Missouri, North Dakota, South Dakota, Nebraska, and Kansas.

program payments and of the MNP model of socio-economic advantage. Of the two count regression models that were posited as possible alternatives in the estimation of the number of types of farm program payments that were received by the farm household in 2004, Table 3 reports only the results pertaining to the $N B N$ regression model. The use of $N B N$ over the Poisson model is because the variance of the dependent variable $(N)$ based on the raw sample is nearly 1.6 times larger than the mean (see Table 3, footnote 2), which provides evidence that its distribution shows signs of overdispersion. As shown in column 1 of Table 3, the fact that the dispersion parameter $\alpha$ is significant under the NBN model makes this model more attractive in terms of fitting the data over the Poisson model. ${ }^{5}$

Estimation of the $N B N$ regression model showed that out of the ten explanatory variables considered, eight variables were found to be significantly associated with the number of farm program participation types $(N) .{ }^{6}$ Of these eight variables, four had a significant positive association, namely, operator's years of education; and three dummy variables indicating that the farmer's main occupation was farming; that the farmer had access to the Internet; and that the farm specialized in cash grain production. The other four variables with a significant yet negative correlation with the number of farm program types that the operator had participated in were whether the farm was fully owned, and when the farm's location, relative to a location in the Midwest, is in the Northeast, South, or West regions. Estimation of this model allowed for the derivation of the fitted values of $N$, which were used in the estimated MNP model of socio-economic well-being.

The base category in the estimated MNP model of socio-economic well-being was "None", which is represented by the "disadvantage" quadrant in the upper left corner of Figure 3. Of the twenty-four explanatory variables used in the estimation, nine were found to significantly increase the likelihood of the farm household falling in the category of "economic" advantage relative to the category of "socio-economic disadvantage". Specifically, and in terms of the life-cycle impacts, column 2 shows farm operators who are 45 years in age or older are more likely to be economically advantaged with the largest likelihood being associated with households where the farm operator is 65 year in age or older. As for the other demographic variables considered, a similar positive impact on the likelihood of economic advantage is found associated with increases in the level of education, and when the farm operator is married, which may be explained respectively by the notion that education

${ }^{5}$ A zero-inflated Poisson model and a zero-inflated $N B N$ model [33] [34] were also investigated but were ultimately not pursued due to lack of convergence.

${ }^{6}$ All standard errors used to discern statistical significance were adjusted for heteroscedasticity using the Huber-White sandwich robust variance estimator based on algorithms contained in STATA [35] [36]. 
Table 2. Summary statistics of variables used in the MNP model of socio-economic advantage, 2004.

\begin{tabular}{|c|c|c|c|c|c|}
\hline \multirow{2}{*}{ Item } & \multicolumn{4}{|c|}{ Advantage status } & \multirow[b]{2}{*}{ All households } \\
\hline & -1 & -2 & -3 & -4 & \\
\hline & Economic & Quality of life & Both & None & \\
\hline \multicolumn{6}{|l|}{ Operator characteristics $^{1}$} \\
\hline Age: $35-44(=1)$ & 0.13 & 0.16 & 0.11 & 0.15 & 0.14 \\
\hline Age: 45-54 (=1) & 0.28 & 0.16 & 0.25 & 0.29 & 0.26 \\
\hline Age: 45-64 (=1) & 0.29 & 0.33 & 0.32 & 0.26 & 0.3 \\
\hline Age: 65 or older $(=1)$ & 0.28 & 0.31 & 0.3 & 0.23 & 0.27 \\
\hline Education, years & $13.84^{*}$ & $12.59^{*}$ & $13.77^{*}$ & 12.87 & 13.29 \\
\hline Gender: male (=1) & 0.94 & 0.91 & 0.93 & 0.88 & 0.91 \\
\hline Marital status: married $(=1)$ & 0.95 & 0.74 & 0.9 & 0.75 & 0.84 \\
\hline Presence of children under $17(=1)$ & 0.29 & 0.36 & 0.27 & 0.29 & 0.3 \\
\hline \multicolumn{6}{|l|}{ Household and farm characteristics ${ }^{2}$} \\
\hline Off-farm income in previous year $(\$ 1000)$ & $57.22^{*}$ & 26.58 & $61.50^{*}$ & 27.49 & 43.02 \\
\hline Number of farm program payments received & 1 & 0.54 & 0.73 & 0.6 & 0.74 \\
\hline Farm sales in previous year $(\$ 1000)$ & $99.41^{*}$ & 40.96 & $89.82^{*}$ & 35.84 & 66.72 \\
\hline More than $50 \%$ of operated acres are rented $(=1)$ & 0.23 & 0.24 & 0.21 & 0.27 & 0.24 \\
\hline Sole proprietorship $(=1)$ & 0.89 & 0.69 & 0.89 & 0.95 & 0.92 \\
\hline Miles to nearest town with a population of 10,000 & $52.74^{*}$ & $47.03^{*}$ & $43.85^{*}$ & 62.61 & 52.95 \\
\hline \multicolumn{6}{|l|}{ County characteristics $^{3}$} \\
\hline County unemployment rate in $2003, \%$ & $5.98^{*}$ & 6.1 & $5.59^{*}$ & 6.13 & 5.97 \\
\hline \% employed in transportation and utilities, 2003 & 2.49 & 2.43 & 2.5 & 2.42 & 2.46 \\
\hline \% employed in finance, insurance, and real estate, 2003 & 5.45 & $5.67^{*}$ & $6.10^{*}$ & 5.27 & 5.56 \\
\hline \% employed in government, 2003 & 15.67 & $15.03^{*}$ & $15.13^{*}$ & 16.24 & 15.62 \\
\hline \% employed in construction, 2003 & 5.95 & $6.10^{*}$ & $6.13^{*}$ & 5.75 & 5.95 \\
\hline \% employed in manufacturing, 2003 & $10.93^{*}$ & $11.92^{*}$ & $11.16^{*}$ & 10.28 & 10.97 \\
\hline Sample size & 2,684 & 879 & 1,533 & 1,610 & 6,706 \\
\hline Expanded number of farms using survey weights & 627,353 & 395,646 & 406,299 & 638,075 & $2,067,373$ \\
\hline Distribution of households (\%) & 30.34 & 19.14 & 19.65 & 30.86 & 100 \\
\hline
\end{tabular}

${ }^{1,2}$ Source: 2004 Agricultural Resource Management Survey. ${ }^{3}$ Sources: Computed by ERS economists based on information from the Bureau of the Census, Bureau of Labor Statistics, Bureau of Economic Analysis, and Office of Management and Budget: County unemployment rate-The ratio of unemployed to the civilian labor force expressed as a percent. Note: The standard deviations of estimates of all continuous variables were estimated using bootstrapping with 1000 resamples. Differences in the means of these estimates in the first, second, and third socio-economic advantage categories and those in the fourth category. (i.e., "None", which indicates socio-economic disadvantage) were examined with ${ }^{*}$ indicating that the respective means within each row were statistically different (at $5 \%$ level confidence interval) from the means in the fourth category).

increases the marginal value of time both on and off the farm [37] [38] and by the increased potential for income pooling associated with marriage [39]. Similarly, and in terms of farm household and farm business characteristics, an increase in the expected income from working off-farm, in the predicted number of farm program types $(N)$ that the farmer might participate in, and in the size of the farm as measured in terms of expected farm sales are all factors that contribute to an increase in the likelihood of economic advantage. ${ }^{7}$ In contrast, having more than $50 \%$ of the farm acreage being rented, having a farm business organized as a sole proprietorship, and the further away is the location of the farm from towns with populations of at least 10,000 are all factors that tend to decrease the likelihood of economic advantage. As for county-related variables, the findings indicate a negative association between increases in the unemployment rate and the likelihood of economic advantage.

\footnotetext{
${ }^{7}$ The finding of the role of farm expansion on economic wellbeing falls in line with a thread of research that has shown the positive impact of larger-sized farms on farm's profitability and farm's success [40] [41].
} 
Table 3. Parameter estimates of count of farm programs and of socio-economic advantage models, $2004^{1}$.

\begin{tabular}{|c|c|c|c|c|}
\hline \multirow[b]{2}{*}{ Variables } & \multirow{2}{*}{$\begin{array}{c}\text { Count of } \\
\text { farm programs }\end{array}$} & \multicolumn{3}{|c|}{ Advantage status ${ }^{3}$} \\
\hline & & Economic & Quality of life & Both \\
\hline Intercept & $-0.8214^{* *}$ & $-4.2355^{* * *}$ & -0.9493 & $-2.6673^{* * *}$ \\
\hline Age: $35-44$ & -- & $0.8111^{* *}$ & 0.3419 & 0.0306 \\
\hline Age: $45-54$ & -- & $0.7013^{* *}$ & -0.0445 & -0.0512 \\
\hline Age: 55-64 & -- & $1.1679^{* * *}$ & $0.7761^{* *}$ & 0.473 \\
\hline Age: 65 or older & -- & $1.6386^{* * *}$ & $0.7783^{*}$ & $0.9476^{*}$ \\
\hline Operator age, years & 0.0021 & -- & -- & -- \\
\hline Operator age, squared & 0.0001 & -- & -- & -- \\
\hline Education, years & $0.0228^{*}$ & $0.1238^{* * *}$ & -0.02 & $0.1001^{* * *}$ \\
\hline Gender: male & -- & 0.2484 & 0.1995 & 0.2956 \\
\hline Marital status: married & & $1.0996^{* * *}$ & -0.1906 & $0.4756^{* * *}$ \\
\hline Presence of children under 17 & -- & -0.1297 & $0.5598^{* * *}$ & -0.0307 \\
\hline Occupation of operator: farming/ranching & $0.6115^{* * *}$ & -- & -- & -- \\
\hline Off-farm income in previous year $(\$ 1000)$ & -- & $0.0187^{* * *}$ & 0.0023 & $0.0190^{* * *}$ \\
\hline Predicted count of farm programs & -- & $0.4718^{*}$ & 0.1433 & -0.8249 \\
\hline Predicted count of farm programs ${ }^{*}$ Age: $35-44$ & -- & -0.2323 & -0.3097 & 0.7926 \\
\hline Predicted count of farm programs ${ }^{*}$ Age: $45-54$ & -- & -0.0666 & -0.0735 & $1.0094^{*}$ \\
\hline Predicted count of farm programs ${ }^{*}$ Age: 55-64 & -- & -0.3229 & -0.2478 & 0.9192 \\
\hline Predicted count of farm programs ${ }^{*}$ Age: 65 or older & -- & -0.0719 & 0.0322 & $1.1516^{*}$ \\
\hline Farm sales in previous year $(\$ 1000)$ & -- & $0.0024^{* * *}$ & 0.0007 & $0.0024^{* * *}$ \\
\hline More than $50 \%$ of operated acres are rented & -- & $-0.2841^{* *}$ & -0.0595 & $-0.2277^{*}$ \\
\hline Sole proprietorship & -- & $-0.3182^{*}$ & 0.1572 & $-0.3406^{*}$ \\
\hline Miles to nearest town with a population of 10,000 & -- & $-0.0024^{* *}$ & $-0.0048^{* * *}$ & $-0.0051^{* * *}$ \\
\hline Acreage is fully owned & $-0.4582^{* * *}$ & -- & -- & -- \\
\hline Farm has a computer with an Internet access & $0.1831^{* * *}$ & -- & -- & -- \\
\hline Farm production: cash grains and oilseeds & $0.7262^{* * *}$ & -- & -- & -- \\
\hline Farm location: Northeast region & $-0.8050^{* * *}$ & -- & -- & -- \\
\hline Farm location: South region & $-0.9125^{* * *}$ & -- & -- & -- \\
\hline Farm location: West region & $-1.0840^{* * *}$ & -- & -- & -- \\
\hline County unemployment rate in $2003, \%$ & -- & $-0.0401^{*}$ & -0.0278 & $-0.1481^{* * *}$ \\
\hline \% employed in transportation and utilities, 2003 & -- & -0.0014 & 0.0025 & 0.0057 \\
\hline \% employed in finance, insurance, and real estate, 2003 & -- & -0.0087 & 0.0331 & $0.0654^{* * *}$ \\
\hline \% employed in government, 2003 & -- & -0.005 & -0.0083 & -0.0035 \\
\hline \% employed in construction, 2003 & -- & 0.0115 & 0.0149 & -0.0018 \\
\hline \% employed in manufacturing, 2003 & -- & 0.0084 & $0.0178^{* * *}$ & $0.0184^{* * *}$ \\
\hline$\alpha$ & $0.0177^{* * *}$ & & & \\
\hline Log pseudo-likelihood $=$ & $-2,026,859$ & & $-2,417,256$ & \\
\hline
\end{tabular}

${ }^{1}$ Primary data source: 2004 Agricultural Resource Management Survey. ${ }^{2}$ Negative binomial regression model. The un-weighted mean, variance, skewness, and kurtosis of the count index $\mathrm{N}$ are, respectively, 1.02, 1.59, 1.05, and 3.06. ${ }^{3}$ Multinomial probit regression model where the base socio-economic advantage category is "None". Note: Statistical significance of estimated parameters is based on Huber-White robust standard errors. " $\mathrm{p}$ $<0.10 ;{ }^{* *} \mathrm{p}<0.05 ;{ }^{* * *} \mathrm{p}<0.01$.

Findings in column 3 indicate the absence of any demographic or household variables that are associated with a higher likelihood of being in a "quality-of-life" category except for those variables denoting that the age of the farm operator is 55 years or older and that the household has children who are 17 years old or younger. As for farm- and county-related variables, the findings respectively indicate that while the likelihood of a QOL advantage appears to decrease the further away is the location of the farm from towns with populations of at least 10,000 , such a likelihood increases with an increase in the percentage of those in the labor force in the farmer's county who are employed in manufacturing. 
Demographic factors that increase the likelihood of a farmer being both "economically" and "quality-of-life" advantaged are those related to when the farmer is 65 years of age or older, when the farmer is married, and when there is an increase in the level of farmer's education (see column 4). Findings also indicate an increase in the likelihood of the farmer being in this socio-economically "advantaged" group when an increase occurs in the income from off-farm work and in farm size. Additionally, higher likelihood of this combined socio-economic advantage occurs when households of those farm operators in the " 45 - 54" and "65 or older" age categories increase the number of types of farm programs that they participate in. Factors that decrease the likelihood of "economic and quality-of-life" advantage are when the farm is organized as a sole proprietorship, when the operator is faced with an increased commuting distance to a town with a population of 10,000 or more, and when the greater majority of the operated farm acreage (i.e., more than 50\%) is rented rather than being partly or fully owned. With regard to the county variables, while increases in the unemployment rate has, and as would be expected, a negative impact on the likelihood of a combined economic and quality-of-life advantage, increases in the county's labor force in finance, insurance, and real estate has positive impact on such likelihood.

The finding that farm households with aging farm operators are more likely to be in the category of "economic" advantage only or in the category of both "economic" and "quality-of-life" advantage is supported also by observed data from the 2004 ARMS. Specifically, these data show that the combined income and annuitized wealth measure, which is the underlying economic component of the socio-economic advantage index used in the analysis, tends to increase steadily across the age profiles of farm operators, from an average of nearly $\$ 84,000$ for those who are younger than 35 years to about $\$ 144,000$ for those who are 65 years or older. The 2004 data also show an inverted- $U$ age-income and age-wealth profiles where the average income of households of farm operators who were younger than 35 years was at about $\$ 62,000$ and average net worth at $\$ 406,300$, with both increasing steadily with age, and with income peaking at near $\$ 92,000$ for those in the 45 - 54 age category and with wealth peaking at near $\$ 881,500$ for those in the 55 - 64 year old age groups. Wealth accumulation of the farm household seems to accelerate throughout the life of the farm operator only to be made available for consumption at the time when income starts to decline at or close to retirement; consistent, in general, with the life-cycle hypothesis [42] [43].

\section{Summary and Concluding Remarks}

Taken together, this research, which develops based on data from the 2004 ARMS a socio-economic well-being index that takes into consideration the economic position of the farm household and the quality of life in the community where the farm operator lives, asserts the importance of improvement in the levels of human capital of the farmers, expansion of farm size, a continued role of farm program participation, and of improved macroeconomic conditions in local areas.

Among the main findings of this paper is the importance of farm programs to the socioeconomic wellbeing of the aging farm household. Specifically, findings indicate a stronger increase in the likelihood of a farm household falling in an "economically and quality-of-life" advantaged category when the farm operator is 65 year in age or older and when the farming strategy of this operator centers on the utilization of a larger number of the available types of farm programs. Because farmers aged 65 years or older represent the fastest growing group of all farmers [14], determination of how best to ensure the continuity of family farms in general, and the economic viability of older farmers who wish to continue farming in particular, is a central rural-development policy question [44]. While many programs seem to exist for young and beginning farmers (e.g., providing lower interest rates on down payment loan programs, increased percentage of total loan funding in the Credit title of the Food, Conservation and Energy Act of 2008 [45]), the existence of clearly defined well-being-enhancing strategies for older farmers has long been lacking [46]. Findings from this paper clearly demonstrate that elderly farmers with astute farm-related managerial skills can, among others, enhance their economic position by adopting a farm production strategy that involves increased utilization of the various types of available farm programs. To the extent that this research is based on a one-year timeframe, it is important that these findings should be caveated since crop and livestock returns in particular, among other agricultural commodities, in addition to farm program payments, may exhibit inter-year variation.

\section{Acknowledgements}

The author is appreciative of the comments provided by an anonymous reviewer of the manuscript. Any remaining errors are the author's own. 


\section{References}

[1] Carlin, T.A. (1972) Farm Families Narrowed the Income Gap during the 1960's. Agricultural Finance Review, 33, 2226.

[2] Carlin, T.A. and Reinsel, E.I. (1973) Combining Income and Wealth: An Analysis of Farm Family Well-Being. American Journal of Agricultural Economics, 55, 38-44. http://dx.doi.org/10.2307/1238659

[3] Mishra, A.K., El-Osta H.S., M.J. Morehart, Johnson J.D. and Hopkins, J.W. (2002) Income, Wealth, and the Economic Well-Being of Farm Households. Agricultural Economic Report No. 812, Economic Research Service, U.S. Department of Agriculture, Washington DC.

[4] Houthakker, H.S. (1967) Economic Policy for the Farm Sector. American Enterprise Institute for Public Policy Research, Washington DC.

[5] Ahearn, M. (1986) An Income Comparison of Farm and Nonfarm People. In: New Dimensions in Rural Policy: Building upon Our Heritage, Joint Economic Committee of the U.S. Congress, 99th Congress, 2nd Session, 99-153.

[6] Offutt, S. (2000) Can the Farm Policy Problem Be Solved? M.E. Lecture, Pennsylvania State University.

[7] Bernanke, B. (2012) Economic Measurement. The 32nd General Conference of the International Association for Research in Income and Wealth, Cambridge, Massachusetts.

http://www.federalreserve.gov/newsevents/speech/bernanke20120806a.htm

[8] Strickland, R.P. (1982) Alternative Indicators of Farm Operators’ Earnings. Agricultural Economics Research, 34, 2833.

[9] El-Osta, H. and Morehart, M. (2009) Welfare Decomposition in the Context of the Life Cycle of Farm Operators: What Does a National Survey Reveal? Agricultural and Resource Economics Review, 38, 125-141.

[10] Boehlje, M. (1973) The Entry-Growth-Exit Processes in Agriculture. Southern Journal of Agricultural Economics, 5, 23-36.

[11] Boehlje, M. (1992) Alternative Models of Structural Change in Agriculture and Related Industries. Agribusiness, 8, 219-231. http://dx.doi.org/10.1002/1520-6297(199205)8:3<219::AID-AGR2720080303>3.0.CO;2-T

[12] Gale Jr., H.F. (1994) Longitudinal Analysis of Farm Size over the Farmer's Life Cycle. Review of Agricultural Economics, 16, 113-123. http://dx.doi.org/10.2307/1349526

[13] Gale Jr., H.F. (2003) Age-Specific Patterns of Exit and Entry in U.S. Farming, 1978-1997. Review of Agricultural Economics, 25, 168-186. http://dx.doi.org/10.1111/1467-9353.00052

[14] National Agricultural Statistics Service (NASS) (2007) Census of Agriculture: Farmers by Age. National Agricultural Statistics Service. http://www.agcensus.usda.gov/Publications/2007/Online Highlights/Fact Sheets/Demographics/

[15] Whitener, L. and Parker, T. (2005) Policy Options for a Changing Rural America. Amber Waves, 5, 58-65.

[16] Robison, L.J. and Barry, P. (1987) The Competitive Firm’s Response to Risk. MacMillan Publishing Co., New York.

[17] Goodwin, B.K. (1993) An Empirical Analysis of the Demand for Multiple Peril Crop Insurance. American Journal of Agricultural Economics, 75, 425-434. http://dx.doi.org/10.2307/1242927

[18] Harwood, J., Heifner, R., Coble, K., Perry, J. and Somwaru, A. (1999) Managing Risk in Farming-Concepts, Research, and Analysis. Agricultural Economic Report No. 774. Economic Research Service, U.S. Department of Agriculture, Washington, DC.

[19] Barnard, C.H., Whittaker, G., Westenbarger, D. and Ahearn, M. (1997) Evidence of Capitalization of Direct Government Payments into U.S. Cropland Values. American Journal of Agricultural Economics, 79, 1642-1650. http://dx.doi.org/10.2307/1244396

[20] El-Osta, H. and Ahearn, M. (1996) Estimating the Opportunity Cost of Unpaid Farm Labor for US Farm Operators. Technical Bulletin No. 1848. Economic Research Service, U.S. Department of Agriculture, Washington DC.

[21] Ahearn, M.C., El-Osta, H. and Dewbre, J. (2006) The Impact of Coupled and Decoupled Government Subsidies on Off-Farm Labor Participation of U.S. Farm Operators. American Journal of Agricultural Economics, 88, 393-408. http://dx.doi.org/10.1111/j.1467-8276.2006.00866.x

[22] El-Osta, H., Mishra, A.K. and Ahearn, M.C. (2004) Labor Supply by Farm Operators under “Decoupled” Farm Program Payments. Review of Economics of the Household, 2, 367-385. http://dx.doi.org/10.1007/s11150-004-5653-7

[23] Weisbrod, B.A. and Hansen, W.L. (1968) An Income-Net Worth Approach to Measuring Economic Welfare. American Economic Review, 58, 1315-1329.

[24] Daganzo, C. (1979) The Multinomial Probit: The Theory and Its Application to Demand Forecasting. Academic Press, New York.

[25] Bunch, D.S. (1991) Estimability in the Multinomial Probit Model. Transportation Research Part B: Methodological, 
25, 1-12. http://dx.doi.org/10.1016/0191-2615(91)90009-8

[26] White, T.K. and Hoppe, R.A. (2012) Changing Farm Structure and the Distribution of Farm Payments and Federal Crop Insurance. Economic Information Bulletin No. 91. Economic Research Service, U.S. Department of Agriculture, Washington, DC.

[27] Blundell, R., Griffith, R. and Van Reenen, J. (1995) Dynamic Count Data Models of Technological Innovation. The Economic Journal, 105, 333-344. http://dx.doi.org/10.2307/2235494

[28] Gourieroux, C., Monfort, A. and Trognon, A. (1984) Pseudo Maximum Likelihood Methods: Applications to Poisson Models. Econometrica, 52, 701-720. http://dx.doi.org/10.2307/1913472

[29] Cameron, A.C. and Trivedi, P.K. (1998) Regression Analysis of Count Data. Cambridge University Press, New York. http://dx.doi.org/10.1017/CBO9780511814365

[30] Greene, W.H. (2002) Econometric Analysis. 5th Edition, Prentice Hall, Englwood Cliffs.

[31] El-Osta, H. (2007) The Determinants of a Quality of Life Indicator for Farm Operator Households: Application of Zero-Inflated Count-Data Models. Applied Research in Quality of Life, 2, 145-163. http://dx.doi.org/10.1007/s11482-007-9035-1

[32] Long, J.S. (1997) Regression Models for Categorical and Limited Dependent Variables. Sage Publications, Inc., Thousand Oaks.

[33] Hausman, J., Hall, B.H. and Griliches, Z. (1984) Econometric Models for Count Data with an Application to the Patents-R \& D Relationship. Econometrica, 52, 909-938. http://dx.doi.org/10.2307/1911191

[34] Lambert, D. (1992) Zero-Inflated Poisson Regression, with an Application to Defects in Manufacturing. Technometrics, 34, 1-14. http://dx.doi.org/10.2307/1269547

[35] Huber, P.J. (1967) The Behavior of Maximum Likelihood Estimates Under Nonstandard Conditions. In: Proceedings of the Fifth Berkeley Symposium on Mathematical Statistics and Probability, Volume 1: Statistics, University of California Press, Berkeley, 221-233.

[36] White, H. (1980) A Heteroskedasticity-Consistent Covariance Matrix Estimator and a Direct Test for Heteroskedasticity. Econometrica, 48, 817-838. http://dx.doi.org/10.2307/1912934

[37] Huffman, W.E. (1980) Farm and Off-Farm Work Decisions: The Role of Human Capital. The Review of Economics and Statistics, 62, 14-23. http://dx.doi.org/10.2307/1924268

[38] Sumner, D (1982) The Off-Farm Labor Supply of Farmers. American Journal of Agricultural Economics, 64, $499-509$. http://dx.doi.org/10.2307/1240642

[39] Marchant, M. (1997) Bargaining Models for Farm Household Decision Making: Discussion. American Journal of Agricultural Economics, 79, 602-604. http://dx.doi.org/10.2307/1244158

[40] Strickland, R.P. (1983) The Negative Income of Small Farms. Agricultural Economics Research, 35, 1, 52-55.

[41] Johnson, J. and Baum, K. (1986) Whole Farm Survey Data for Economic Indicators and Performance Measures. Agricultural Economics Research, 38, 1-13.

[42] Ando, A. and Modigliani, F. (1963) The “Life Cycle” Hypothesis of Saving: Aggregate Implications and Tests. American Economic Review, 53, 55-84.

[43] Modigliani, F. (1986) Life Cycle, Individual Thrift, and the Wealth of Nations. The American Economic Review, 76, 297-313.

[44] Mishra, A.K., El-Osta, H.S. and Shaik, S. (2010) Succession Decisions in U.S. Family Farm Businesses. Journal of Agricultural and Resource Economics, 35, 133-152.

[45] Sureshwaran, S. and Ritchie, S. (2011) U.S. Farm Bill Resources and Programs for Beginning Farmers. Choices, 26. http://www.choicesmagazine.org/choices-magazine/theme-articles/innovations-to-support-beginning-farmers-and-ranc hers/us-farm-bill-resources-and-programs-for-beginning-farmers-

[46] Skolnik, A.M. (1952) Economic Security of Farm Operators. Social Security Bulletin, 15, 3-9, 21. 
Scientific Research Publishing (SCIRP) is one of the largest Open Access journal publishers. It is currently publishing more than 200 open access, online, peer-reviewed journals covering a wide range of academic disciplines. SCIRP serves the worldwide academic communities and contributes to the progress and application of science with its publication.

Other selected journals from SCIRP are listed as below. Submit your manuscript to us via either submit@scirp.org or Online Submission Portal.
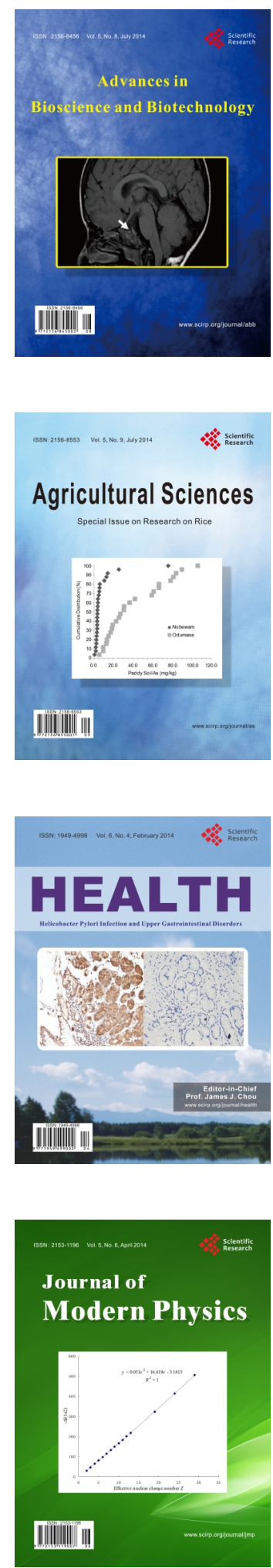
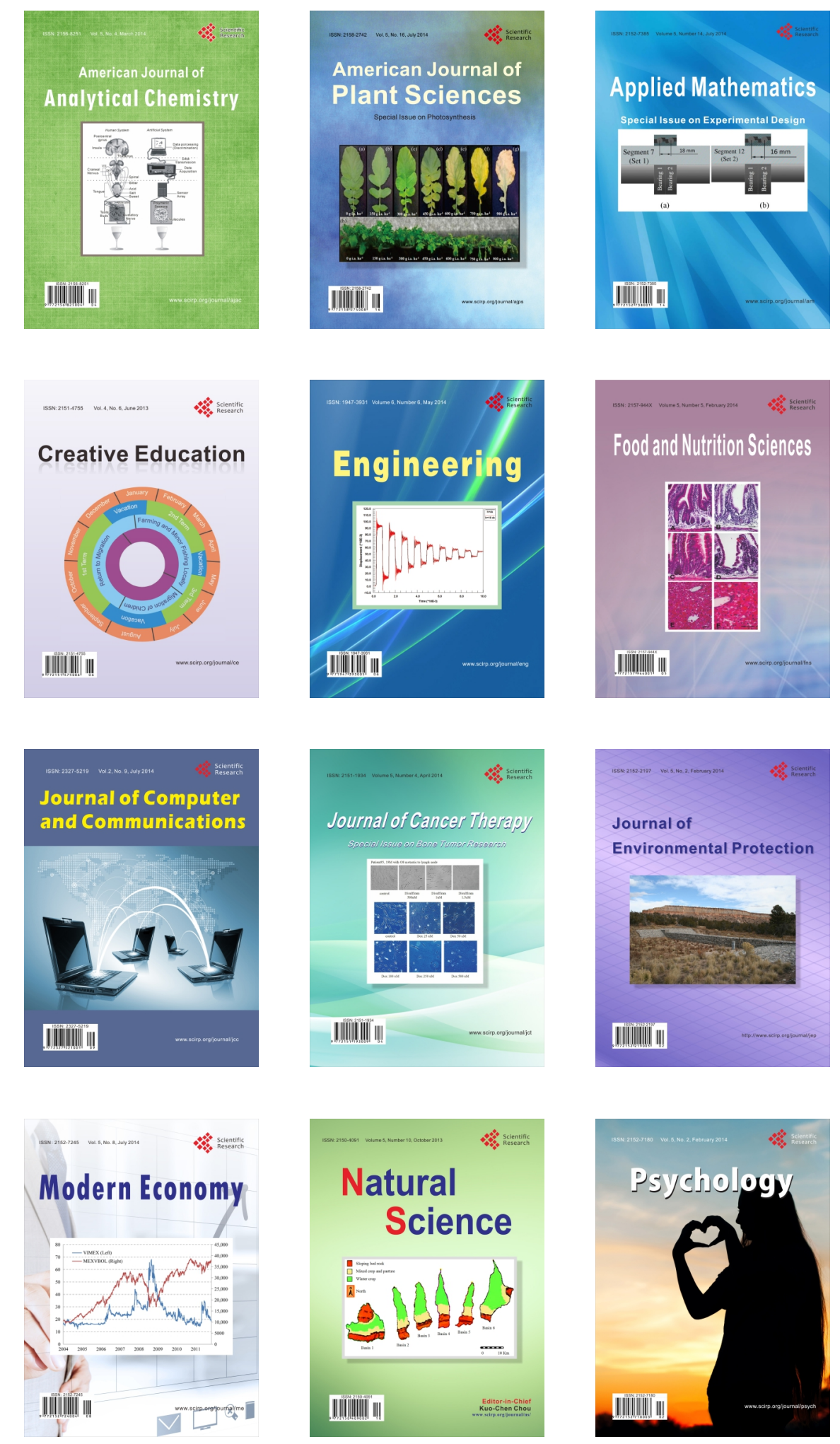